\title{
The influence of the silica/sodium ratio on the fly ash geopolymer binder
}

\author{
V. Bocullo, D. Vaičiukynienė, V. Vaitkevičius \\ Department of Building Materials, Kaunas University of Technology, \\ Studentu St. 48, LT-51367 Kaunas, Lithuania \\ E-mail: danute.palubinskaite@ktu.lt
}

\begin{abstract}
A. Kantautas
Department of Silicate Technology, Kaunas University of Technology, Radvilenu St. 19, LT-50270 Kaunas, Lithuania
\end{abstract}

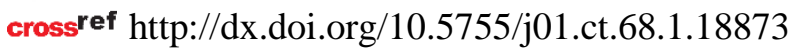

Received 17 May 2016; Accepted 28 April 2017

\begin{abstract}
This article investigates the properties of a geopolymer, an alternative binding material to the ordinary Portland cement (OPC), and their dependence on different $\mathrm{SiO}_{2} / \mathrm{Na}_{2} \mathrm{O}$ ratios in the system. To make the geopolymer polish coal burning fly ash consisting mainly of amorphous $\mathrm{SiO}_{2}$ and $\mathrm{Al}_{2} \mathrm{O}_{3}$, it was activated with a $\mathrm{NaOH}$ solution. While many researches have been done on the $\mathrm{Si} / \mathrm{Al}$ ratio influence, not many studies have examined the activator solution influence on geopolymer properties. Samples were made with 8 different mix compositions with the $\mathrm{SiO}_{2} / \mathrm{Na}_{2} \mathrm{O}$ ratio varying within 0.8-3.1. The samples were tested for compressive strength after 7, 14 and 28 days of curing. The mineral composition of each set mix was examined with XRD. Samples with the $\mathrm{SiO}_{2} / \mathrm{Na}_{2} \mathrm{O}$ ratio equal to 2.0 showed the highest compressive strength. The XRD of these samples showed the presence of low-crystallinity hydrosodalite and a small amount of mullite and quartz. The acceptable strength was shown by samples with the $\mathrm{SiO}_{2} / \mathrm{Na}_{2} \mathrm{O}$ ratio in the range of 1.5-2.5. Samples with the ratio beyond this range failed to produce enough of the necessary binding agents.
\end{abstract}

Key words: alkali-activated, geopolymer, fly ash, binding materials, compressive strength, chemical composition

\section{Introduction}

Geopolymer binder is an ecological alternative to the ordinary Portland cement (OPC). OPC is the most widely used material in the construction industry worldwide, but it has a high level of $\mathrm{CO}_{2}$ emissions [1] because of clinker reactions and high manufacturing temperatures. To produce $1 \mathrm{t}$ of OPC $0.5-0.94 \mathrm{t}$ of $\mathrm{CO}_{2}$ is emitted depending on the clinker ratio in the cement [2] due to chemical reactions where carbon dioxide is a product, and high temperatures are needed for this reaction to occur. Currently, OPC is one of the most popular building materials in the world [3], with the current consumption of $1 \mathrm{~m}^{3}$ per person per year [4]. Because of this fact, the OPC manufactures are causing at least $5-8 \%$ of the global $\mathrm{CO}_{2}$ emissions $[4,5]$.

Geopolymer binding materials or geopolymer cements are mineral molecular networks or chains bound by covalent bonds [6] and having the chemical composition similar to that of zeolites, but with a more amorphous microstructure [7].

A geopolymer is obtained by activating the $\mathrm{SiO}_{2}$ and $\mathrm{Al}_{2} \mathrm{O}_{3}$ source material with an alkali activator
[8]. Usually, the source materials are various industry by-products like fly ash (FA), granulated blast furnace slag (GBFS), waste of fluid catalyst cracking (FCC) or any material rich in $\mathrm{SiO}_{2}$ and $\mathrm{Al}_{2} \mathrm{O}_{3}$.

A simplified explanation of geopolymerisation can be described as several processes that occur parallel to each other: first, reactive silicates and aluminates are leached from aluminosilicate raw materials into the alkali activator solution (usually sodium hydroxide or waterglass or combination of the two); then polycondensation takes place - the released $\mathrm{Si}$ - and $\mathrm{Al}$ - tetrahedrals are polycondensed into amorphous or semi-crystalline oligomers, and different types of oligomers further polymerize forming a hardened three-dimensional synthetic network of aluminosilicates, also called geopolymer gel $[9,10]$. The empirical formula of geopolymers, also known as poly(sialates), is as follows:

$$
\mathrm{Mn}\left\{-\left(\mathrm{SiO}_{2}\right)_{z}-\mathrm{AlO}_{2}\right\}_{n} \cdot \mathrm{wH}_{2} \mathrm{O}
$$

where $\mathrm{M}-\mathrm{a}$ cation such as $\mathrm{K}^{+}, \mathrm{Na}^{+}$or $\mathrm{Ca}^{2+} ; n-$ the degree of polycondensation, $z-1,2$ or 3 [11]. 
According to many studies, the concrete with a geopolymer binder has an equivalent strength as that of concrete with OPC. Also, it has been proven that the geopolymer concrete has a better resistance to acid attacks [12] and is more fire- and heat-resistant [13].

According to various studies, the properties of geopolymers can be affected by many factors such as the chemical composition of the raw material, the amount of activator [9]. While there are plenty of different studies on the $\mathrm{SiO}_{2} / \mathrm{Al}_{2} \mathrm{O}_{3}$ or $\mathrm{Na}_{2} \mathrm{SiO}_{3} / \mathrm{NaOH}$ (alkali activators) ratios, there is a lack of research on the $\mathrm{SiO}_{2} / \mathrm{Na}_{2} \mathrm{O}$ ratio where the effect on the geopolymer of different amounts of the alkali activator is studied. In the present research, the influence of the $\mathrm{SiO}_{2} / \mathrm{Na}_{2} \mathrm{O}$ ratio on the geopolymer compressive strength and chemical composition is studied.

\section{Materials and methods}

In this study, low calcium coal burning fly ash (FA) from Poland was used as a raw material for geopolymers. Currently, 750 million tons of coal FA are generated in the world every year and over 40 million tons in Europe [11]. At the moment, only $39 \%$ of FA are utilised in the US and $47 \%$ in Europe, while the global average is estimated to be close to $25 \%$ [14].

Because of its chemical composition (high amounts of amorphous $\mathrm{SiO}_{2}$ and $\mathrm{Al}_{2} \mathrm{O}_{3}$ ) FA may be utilized as a raw material for geopolymers [11, 15].

The XRFA elemental analysis was used to determine the chemical composition of the fly ash type F. Its elemental composition was recalculated to oxides (Table 1).

Table 1. Fly ash type F chemical composition

\begin{tabular}{|c|c||c|c|}
\hline Oxide & $\begin{array}{c}\text { Amount, } \\
\%\end{array}$ & Oxide & $\begin{array}{c}\text { Amount, } \\
\%\end{array}$ \\
\hline $\mathrm{CaO}$ & 3.683 & $\mathrm{P}_{2} \mathrm{O}_{5}$ & 1.310 \\
\hline $\mathrm{SiO}_{2}$ & 49.468 & $\mathrm{SrO}$ & 0.106 \\
\hline $\mathrm{Na}_{2} \mathrm{O}$ & 0.945 & $\mathrm{ZrO}_{2}$ & 0.147 \\
\hline $\mathrm{Al}_{2} \mathrm{O}_{3}$ & 27.452 & $\mathrm{SO}_{3}$ & 0.921 \\
\hline $\mathrm{MnO}$ & 0.063 & $\mathrm{ZnO}$ & 0.050 \\
\hline $\mathrm{MgO}$ & 1.699 & $\mathrm{TiO}_{2}$ & 1.658 \\
\hline $\mathrm{K}_{2} \mathrm{O}$ & 4.539 & $\mathrm{CuO}$ & 0.027 \\
\hline $\mathrm{Fe}_{2} \mathrm{O}_{3}$ & 7.379 & $\mathrm{NiO}$ & 0.031 \\
\hline $\mathrm{BaO}$ & 0.436 & $\mathrm{PbO}$ & 0.038 \\
\hline
\end{tabular}

The XRD analysis shows peaks of quartz and mullite. The presence of amorphous $\mathrm{SiO}_{2}$ is identified as a "hill" on the XRD graphic within the $2 \theta$ degree range in $18^{\circ}-30^{\circ}$ (Fig. 1). High amounts of amorphous $\mathrm{SiO}_{2}$ and $\mathrm{Al}_{2} \mathrm{O}_{3}$ make $\mathrm{FA}$ a good raw material for the geopolymer binding material.

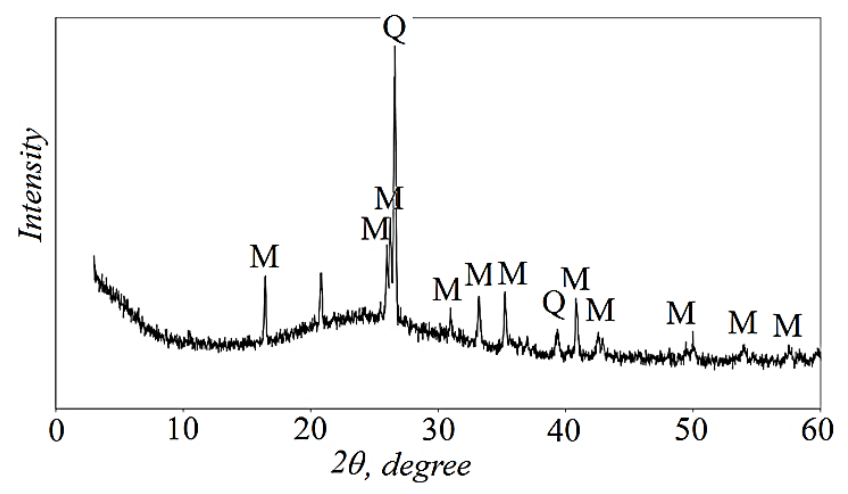

Fig. 1. XRD analysis of Fly ash. M - mullite, $\mathrm{Q}$ - quartz.

The XRD analysis for raw materials was performed at Kaunas University of Technology on a D8 advance diffractometer (Bruker AXS, Karlsruhe, Germany) operating at the tube voltage of $40 \mathrm{kV}$ and the tube current of $40 \mathrm{~mA}$. The X-ray beam was filtered with a Ni $0.02 \mathrm{~mm}$ filter to select the $\mathrm{CuK} \alpha$ wavelength. Diffraction patterns were recorded in a Bragg-Brentano geometry using a fast counting detector Bruker LynxEye based on the silicon strip technology. The specimens were scanned over the range of $2 \theta=3-60^{\circ}$ at a scanning speed of $6 \mathrm{~min}^{-1}$, using a coupled two theta/theta scan type.

The XRFA analysis of the fly ash type $F$ was performed at Kaunas University of Technology on a fluorescence spectrometer S8 Tiger (Bruker AXS, Karlsruhe, Germany) operating at the counter gas Helium 2 bar.

The compressive strength of the samples was tested with a hydraulic press ToniTechnik 2020.

The fly ash was activated with a $\mathrm{NaOH}$ solution. The amount of $\mathrm{NaOH}$ was determined by $\mathrm{SiO}_{2} / \mathrm{Na}_{2} \mathrm{O}$ required for a certain mix. To increase the $\mathrm{Al}_{2} \mathrm{O}_{3}$ level in the mixture, additional $\mathrm{Al}(\mathrm{OH})_{3}$ (gibbsite) was added. In the experiment, 8 different mixtures with different $\mathrm{SiO}_{2} / \mathrm{Na}_{2} \mathrm{O}$ ratios have been studied (Table 2).

Table 2. Mixture design of geopolymer binder

\begin{tabular}{|c|c|c|c|c|c|}
\hline No. & $\begin{array}{c}\mathrm{SiO}_{2} / \mathrm{Na}_{2} \mathrm{O} \\
\text { mol }\end{array}$ & $\begin{array}{c}\mathrm{Al}(\mathrm{OH})_{3}, \\
\text { g }\end{array}$ & $\begin{array}{c}\text { Fly } \\
\text { ash, g }\end{array}$ & $\begin{array}{c}\mathrm{NaOH}, \\
\text { g }\end{array}$ & $\begin{array}{c}\mathrm{H}_{2} \mathrm{O}, \\
\text { g }\end{array}$ \\
\hline 1 & 0.8 & 29.94 & 92.23 & 72.7 & 43.3 \\
\hline 2 & 1.3 & 33.93 & 104.53 & 45.99 & 41.0 \\
\hline 3 & 1.5 & 19.97 & 61.49 & 22.47 & 23.1 \\
\hline 4 & 1.7 & 21.97 & 67.64 & 22.11 & 24.8 \\
\hline 5 & 1.9 & 24.95 & 76.86 & 21.58 & 27.4 \\
\hline 6 & 2 & 25.96 & 79.93 & 21.41 & 28.3 \\
\hline 7 & 2.3 & 29.95 & 92.23 & 20.7 & 31.8 \\
\hline 8 & 3.1 & 39.94 & 122.98 & 18.93 & 40.4 \\
\hline
\end{tabular}


Paste samples were cast into $20 \times 20 \times 20 \mathrm{~mm}$ moulds and left for 24 hours. After this period, the moulds were put into sealed bags to prevent drying and moved to elevated temperatures of $80{ }^{\circ} \mathrm{C}$ to ensure the best conditions for geopolymerisation.

The samples were tested for compressive strength after 7, 14 and 28 days. Crushed samples were ground for the XRD analysis.

The relative hydrosodalite crystality is directly proportional to intensity peaks of the investigated material $[16,17]$. In this case, it was matched to the ratio of the sum of the intensity of occurred hydrosodalite peaks and the sum of the intensity of theoretical hydrosodalite peaks:

$$
C_{r e l}=\frac{I_{a p}}{I_{p r}} \times 100 ;
$$

where $C_{r e l}-$ relative crystality, $\% ; I_{a p}-$ intensity peaks of occurred hydrosadalite, unt.; $I_{p r}$-intensity peaks of theoretical hydrosodalite, unt.

\section{Results and discussion}

The samples were not tested after the first few days, because they were not yet hardened enough. The first test was run 7 days after casting.

As is seen from the strength graph (Fig. 2), the strength is more influenced by the $\mathrm{SiO}_{2} / \mathrm{Na}_{2} \mathrm{O}$ ratio rather than by the curing time. The compressive strength of samples tested by the ratios varied from 5.6 $\mathrm{MPa}$ to the maximum $56.16 \mathrm{MPa}$, while the effect of the curing time was not as significant: in most of the cases (with a few exceptions) the strength gained within the first 7 days remained very similar.

As mentioned before, the main factor for compressive strength was the $\mathrm{SiO}_{2} / \mathrm{Na}_{2} \mathrm{O}$ ratio. The strongest samples were made with this ratio in the range from 1.5 to 2.5. Within this range, the compressive strength was from 32.25 to $56.16 \mathrm{MPa}$. The peak strength $(56.16 \mathrm{MPa})$ was observed at the $\mathrm{SiO}_{2} / \mathrm{Na}_{2} \mathrm{O}$ ratio 2.0. Samples made from mixes that had a different ratio developed a much lower compressive strength.

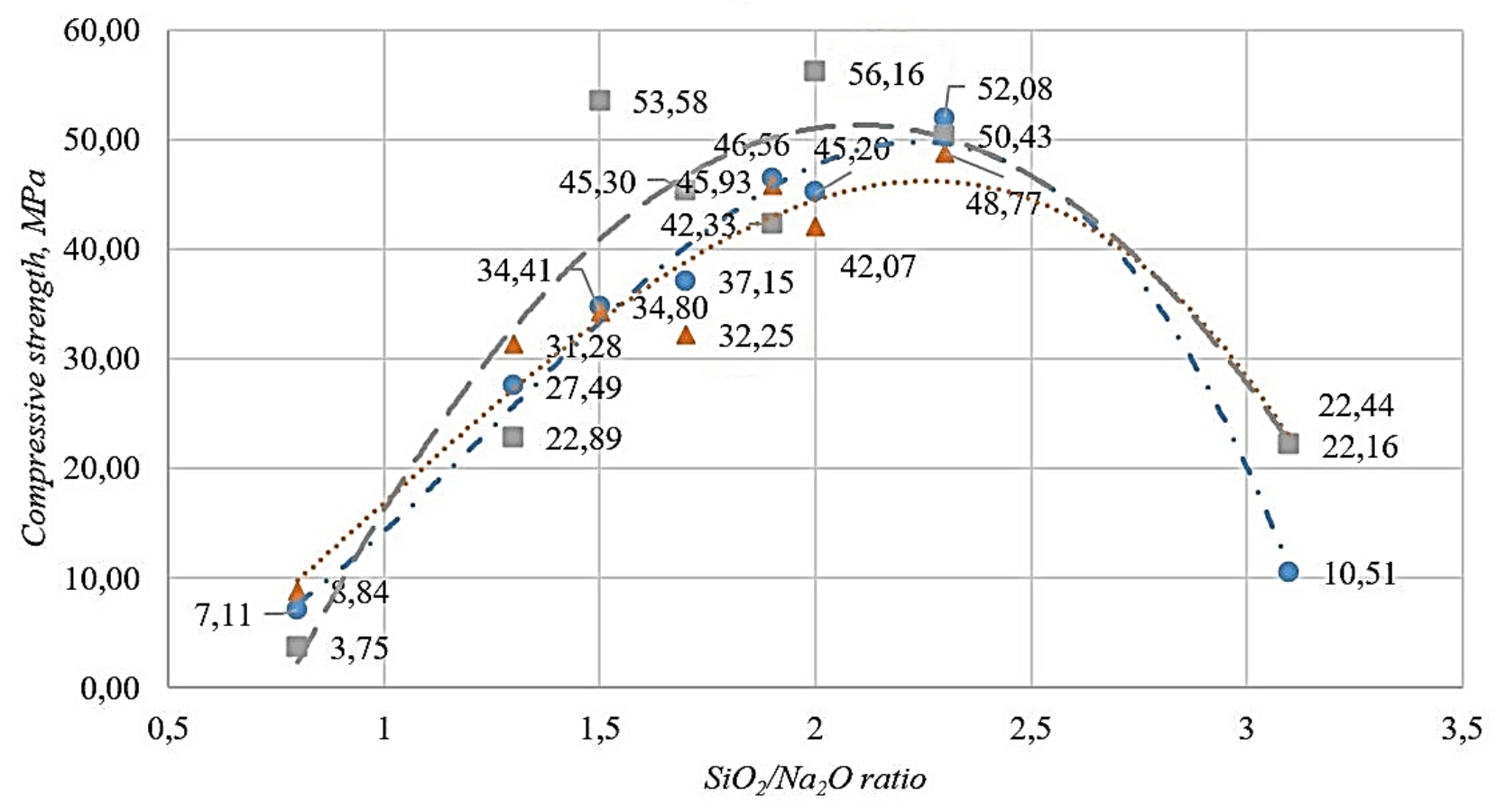

\section{-. - - - After 7 days $\quad \cdots . . \cdots$ After 14 days $\quad$ - $\quad-\quad$ After 28 days}

Fig. 2. Samples of compressive strength depending on the $\mathrm{SiO}_{2} / \mathrm{Na}_{2} \mathrm{O}$ ratio in a mix.

The mineral composition of samples was determined using the XRD analysis. All samples with a different mix composition showed peaks for hydrosodalite (Figs. 3 and 4). The XRD diagram which represents the strongest sample is number 6 (Fig. 4). In this sample, the low-crystallinity hydrosodalite is found with a small amount of mullite and quartz. 


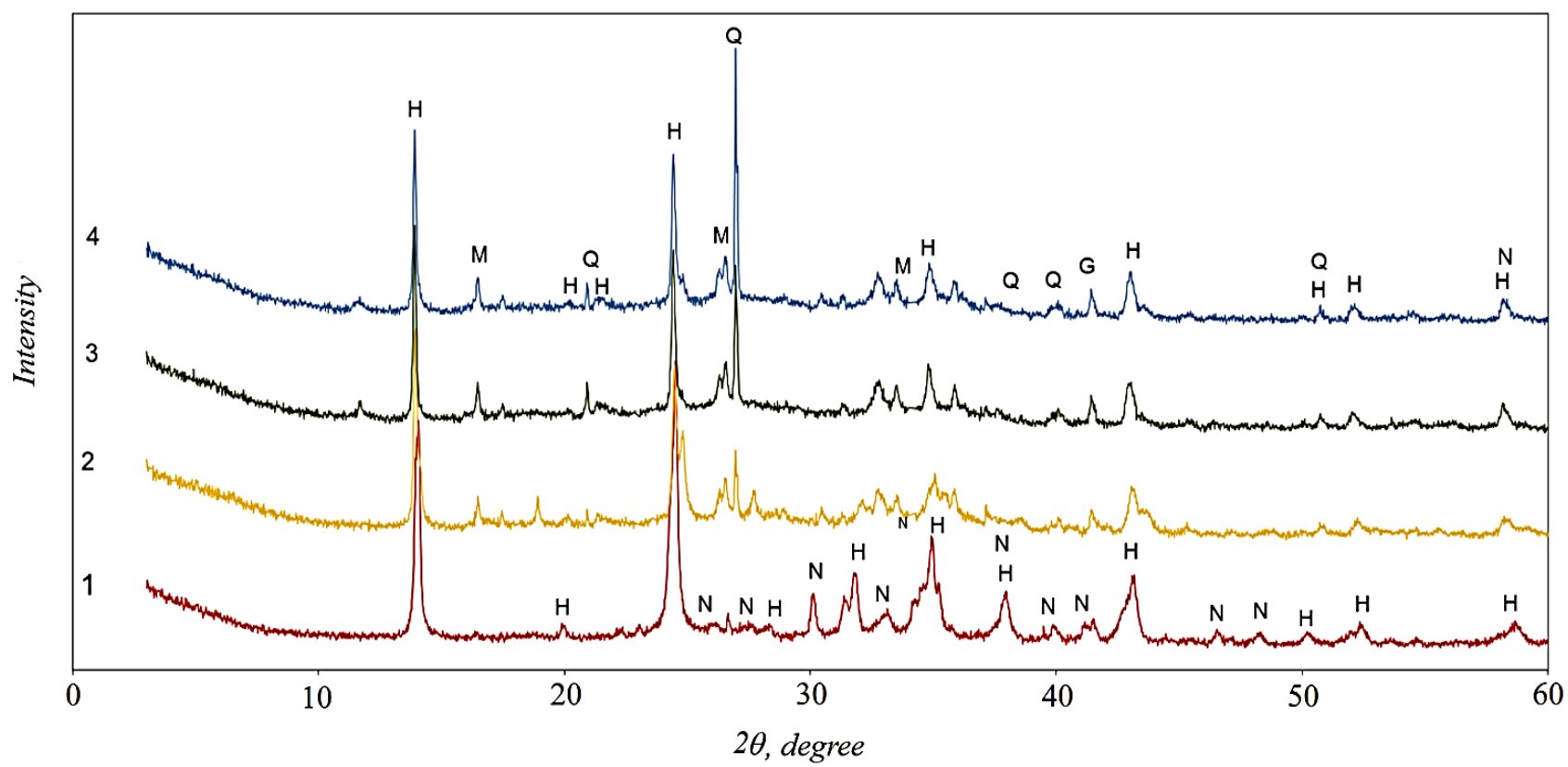

Fig. 3. XRD analysis of 1-4 mix samples. $\mathrm{N}$ - sodium carbonate (natrite), $\mathrm{H}-$ sodium aluminium silicate hydroxide hydrate (hydrosodalite), $\mathrm{M}$ - aluminium silicon oxide (mullite), $\mathrm{Q}$ - silicon oxide ( $\alpha$-quartz).

The weakest samples are marked as number 1 (Fig. 3) and number 8 (Fig. 4). Sample number 1 contained a high-crystallinity hydrosodalite and sodium carbonate, which doesn't provide any strength for the system. Sample number 8 (Fig. 4) had the gibbsite $\left(\mathrm{Al}(\mathrm{OH})_{3}\right)$, which is one of the geopolymer raw materials. In this case, the gibbsite didn't react and not enough of the binding agent was formed, so the system strength was very low.

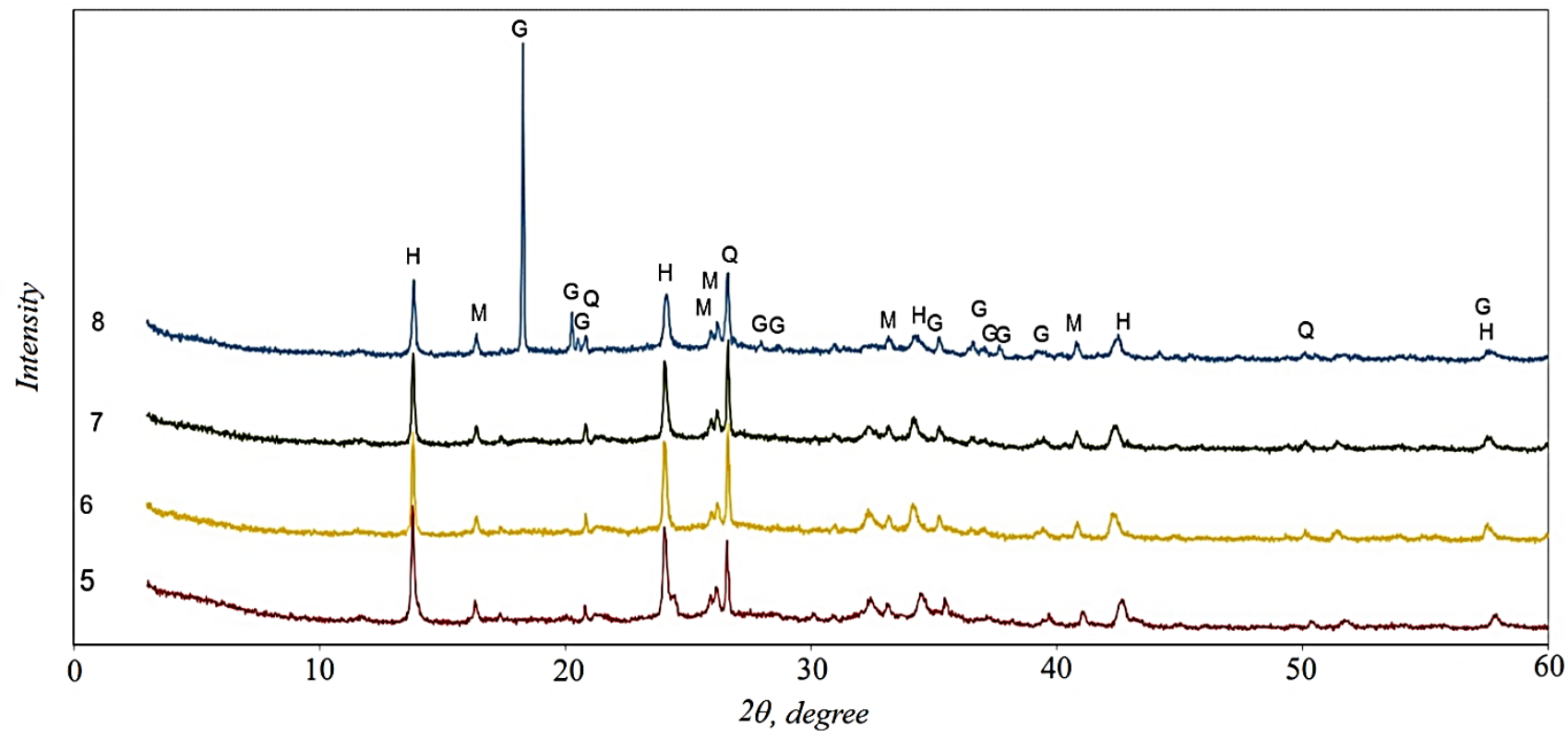

Fig. 4. XRD analysis of 5-8 mix samples. $\mathrm{N}$ - sodium carbonate (natrite), $\mathrm{H}$ - sodium aluminium silicate hydroxide hydrate, $\mathrm{M}$ - aluminium silicon oxide (mullite), Q - silicon oxide ( $\alpha$-quartz), $\mathrm{G}$ - aluminium hydroxide (gibbsite). 


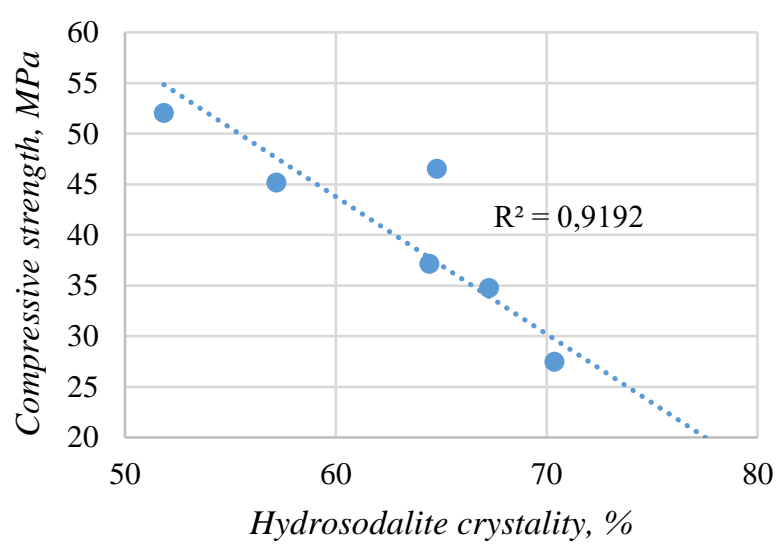

$a$

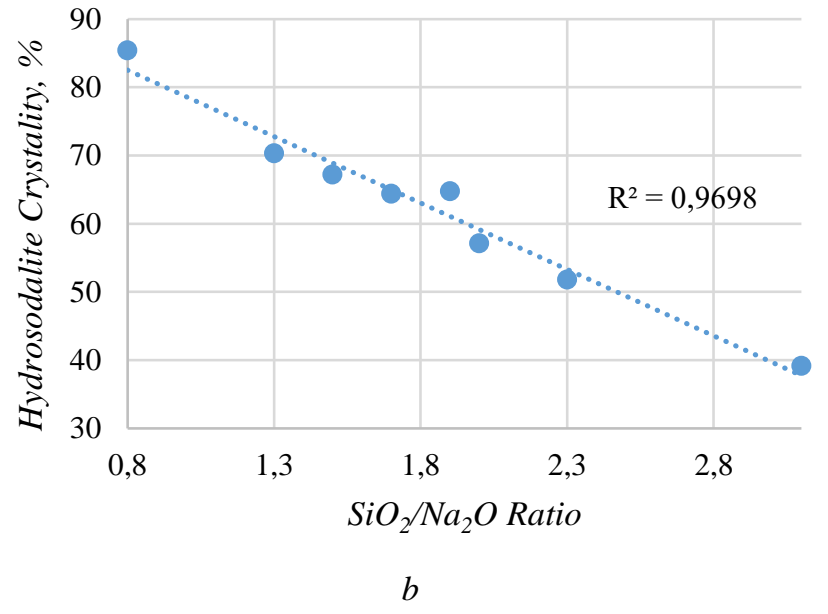

Fig. 5. The influence of hydrosodalite crystality on the compressive strength of samples (a) and the effect of the $\mathrm{SiO}_{2} / \mathrm{Na}_{2} \mathrm{O}$ ratio (b) on hydrosodalite crystallinity.

As is seen in Fig. 5 samples, the compressive strength decreases with a higher hydrosodalite crystallinity (Fig. 5, a). The results indicate that a bigger hydrosodalite crystallinity is obtained with a lower $\mathrm{SiO}_{2} / \mathrm{Na}_{2} \mathrm{O}$ ratio (Fig. 5, b).

\section{Conclusions}

After completing the tests, the following effects were observed:

1. The geopolymer strength can reach $50 \mathrm{MPa}$ and more, which makes it equivalent to OPC.

2. The best $\mathrm{SiO}_{2} / \mathrm{Na}_{2} \mathrm{O}$ ratio to develop the maximum compressive strength is around 2.0. Satisfactory results were observed at the $\mathrm{SiO}_{2} / \mathrm{Na}_{2} \mathrm{O}$ ratio range within $1.5-2.5$, otherwise the system failed to develop binding materials and to gain the compressive strength.

3. A higher $\mathrm{SiO}_{2} / \mathrm{Na}_{2} \mathrm{O}$ ratio decreases the hydrosodalite crystallinity.

\section{References}

1. Nazari A. Compressive strength of geopolymers produced by ordinary Portlandcement: Application of genetic proggramming for design // Materials and Design. 2013. Vol. 43. P. 356-366. http//dx.doi.org/10.1016/ j.matdes.2012.07.012

2. Islam A., et al. The development of compressive strength of ground granulated blast furnace slagpalm oil fuel ash-fly ash based geopolymer mortar // Materials and Design. 2014. Vol. 56. P 833-841. http://dx.doi.org/10.1016/j.matdes.2013.11.080

3. Paris J. M., et al. A review of waste products utilized as supplements to Portland cement in concrete // Journal of Cleaner Production. 2016. Vol. 121. P. 1-18. http://dx.doi.org/ 10.1016/j.jclepro.2016.02.013
4. Turner L. K., Collins F. G. Carbon dioxide wquivalent $\left(\mathrm{CO}_{2}-\mathrm{e}\right)$ emssions: A comparison between geopolymer and OPC cement concrete // Construction and Building Materials. 2013. Vol. 43. P. 125-130. http://dx.doi.org/10.1016/j.conbuildmat.2013.01.023

5. Tashima, M. M., et al. Alkali activated materials based on fluid catalytic cracking catalyst residue (FCC): infulence of $\mathrm{SiO}_{2} / \mathrm{Na}_{2} \mathrm{O}$ and $\mathrm{H}_{2} \mathrm{O} / \mathrm{FCC}$ ratio on mechanical strength and microstructure // Fuel. 2013. Vol. 108. P. 833-839. http://dx.doi.org/ 10.1016/j.fuel.2013.02.052

6. Davidovists J. About: Geopolymer Institute. Geopolymer institute. [Online] May 14, 2014. [Cited: September 20, 2014.] http://www.geopolymer.org/science/introduction.

7. Xu H., Devender J. S. J. Van Deventer. The geopolymerisation of alumino-silicate minerals // Internatinal Journal of Mineral Processing. 2000. Vol. 59. N 3. P. 247-266. http://dx.doi.org/10.1016/S0301-7516(99)00074-5

8. Bocullo V. et al. Geopolimerinis rišiklis gautas iš ceolitinès modifikuotos katalizatoriaus atliekos // Procedings of Junior Science Conference "Statyba ir Architektūra". 2016. P 110-117.

9. Zhang M., et al. Synthesis factors affecting mechanical properties, microstructure, and chemical composition of red mud-fly ash based geopolymers // Fuel. 2014. Vol. 134. P. 315-325. http://dx.doi.org/ 10.1016/j.fuel.2014.05.058

10. Fengd D., Provis J. L., Devender J. S. J. Thermal Activation of Albite for Synthesis of One-Part Mix Geopolymers // J. Am. Ceram. Soc. 2012. Vol. 95. P. 565-572. http://dx.doi.org/ 10.1111/j.1551-2916.2011.04925.x

11. Izquierdoa, Maria, et al. Coal fly ash-slag-based geopolymers: Microstructure and metal leaching // Journal of Hazardous Materials. 2008. Vol. 166. P. 561-566. http://dx.doi.org/10.1016/j.jhazmat.2008.11.063 
12. Bakharev T. Resistance of geopolymer materials to acid attack. // Cement and Concrete Research. 2004. Vol. 35. P 658-670.

http://dx.doi.org/ 10.1016/j.cemconres.2004.06.005

13. Peigang H., et al. Effects of high-temperature heat treatment on the mechanical properties of unidirectional carbon fiber reinforced geopolymer composites // Ceramics International. 2010. Vol. 36. P. 1447-1453. http://dx.doi.org/10.1016/j.ceramint.2010.02.012

14. Blissett R. S., Rowson N. A. A review of the multicomponent utilisation of coal fly ash // Fuel. 2012. Vol. 97. P. 1-23. http://dx.doi.org/ 10.1016/j.fuel.2012.03.024

15. Wallah S. E., Rangan B. V. Low-calcium fly ashbased geopolymer concrete: long-term properties // Research Report GC 2. Perth, 2006. P. 97.

16. Anuwattana R., Khummongkol P. Conventional hydrothermal synthesis of Na-A zeolite from cupola slag and aluminum sludge // Journal of Hazardous Materials. 2009. Vol. 166. P. 227-232. https://doi.org/10.1016/j.jhazmat.2008.11.020

17. Shams K., Mirmohammadi S.J. Preparation of 5A zeolite monolith granular extrudates using kaolin: investigation of the effect of binder on sieving/adsorption properties using a mixture of linear and branched paraffin hydrocarbons // Microporous and Mesoporous Materials. 2007. Vol. 106. P. 268-277. https://doi.org/10.1016/j.micromeso.2007.03.007
V. Bocullo, D. Vaičiukynienė, V. Vaitkevičius, A. Kantautas

\section{SILICIO IR NATRIO SANTYKIO ITAKA LAKIŲJŲ PELENU GEOPOLIMERINEI RIŠAMAJAI MEDŽIAGAI}

\section{S a n tra u k a}

Šiame straipsnyje aptariama alternatyvios ịprastajam portlandcemenčiui rišamosios medžiagos geopolimeru savybiu priklausomybè nuo sistemos $\mathrm{SiO}_{2}$ ir $\mathrm{Na}_{2} \mathrm{O}$ santykio. Geopolimero žaliava - lenkiški lakieji pelenai, turintys savo sudettyje daugiausia $\mathrm{SiO}_{2}$ ir $\mathrm{Al}_{2} \mathrm{O}_{3}$, buvo aktyvuoti $\mathrm{NaOH}$ tirpalu. Pasaulyje atlikta daug tyrimu, kuriuose nagrinèta tik $\mathrm{SiO}_{2}$ ir $\mathrm{Al}_{2} \mathrm{O}_{3}$ santykio itaka geopolimerų savybèms, ir praktiškai nebuvo ištirta aktyvatoriaus ittaka.

Šiame eksperimente buvo pagaminti 8 skirtingu sudečiu bandiniai su $\mathrm{SiO}_{2}$ ir $\mathrm{Na}_{2} \mathrm{O}$ santykiu, kintančiu nuo 0,8 iki 3,1 . Bandinių gniuždymo stipris matuotas po 7 , 14, 28 parų kietejjimo. Nustatyta, kad stipriausi bandiniai gaunami (iki 56,16 MPa), kai buvo naudojamas mišiniụ molinis $\mathrm{SiO}_{2}$ ir $\mathrm{Na}_{2} \mathrm{O}$ santykis 2. XRD analizès rezultatai parodè, kad šiuose bandiniuose vyrauja mažos kristalizacijos hidrosodalitas, mulitas ir kvarcas. Bandiniuose, kuriu $\mathrm{SiO}_{2}$ ir $\mathrm{Na}_{2} \mathrm{O}$ santykis buvo $1,5-2,5$ intervale, gniuždomasis stipris kito nuo $32,25 \mathrm{MPa}$ iki $56,16 \mathrm{MPa}$. Bandinių, kurie nepateko ị ši intervalą $\left(\mathrm{SiO}_{2}\right.$ ir $\mathrm{Na}_{2} \mathrm{O}$ santykis nuo $0,8-1,5$ ir daugiau kaip 2,5), stipris buvo mažas. Tai galima paaiškinti tuo, kad bandiniuose nesusidare tinkamas rišiklio kiekis.

Reikšminiai žodžiai: šarminis aktyvavimas, geopolimeras, lakieji pelenai, rišamosios medžiagos, gniuždomasis stipris. 